area supplied by the Lancashire Electric Power Co., and of the nature of supplies afforded in that area. The $11 \mathrm{kV}$. distribution system and the protective arrangements employed thereon are described, and figures showing availability of supply to consumers during a period of one year are given. The testing necessary to ensure satisfactory functioning of the protective gear is also dealt with. The experience of the Lancashire Electric Power Co. indicates that with a duplicate tail-end feeder system, simple overload and earth-leakage protection will ensure the minimum of interruption of consumers' supplies provided adequate tests are made to prove the reliability of the gear. Where two or more feeders operate in parallel between sending and receiving stations, and provided the load tapped off along the route does not exceed about 50 per cent of the normal load of the feeder, very satisfactory discrimination can be obtained with parallel-feeder protective systems.

In the third paper, by R. W. Steel and A. W. Allwood, systems up to $33 \mathrm{kV}$. are considered, and the importance of installing suitable and efficient protective apparatus on rural networks, at all stages of their development, is emphasized. A typical protective scheme, including are-suppression coils, for an $11 \mathrm{kV}$. and $33 \mathrm{kV}$. rural distribution system which has been put into operation in a particular area of supply is described, and the reasons leading to its adoption are given. The practical difficulties met with in securing efficient operation and of carrying out proper maintenance are discussed and some statistical records of fault interruptions are presented. These indicate the number and type of faults causing total or partial failures of supply and show the conditions under which the protective gear is called upon to function. The nature of the faults which occur on rural networks is analysed and a suggested standard form of keeping fault statistics is put forward for general adoption by undertakings distributing in rural areas.

The fourth paper, by K. I. Brown, deals more particularly with the automatic selective isolation of sustained earth-faults on a network protected by Petersen coils, and explains what is believed to be a unique method evolved for the protection of a grid network of $37.5 \mathrm{kV}$. transmission lines against lineto-earth faults, which enables automatic selection and isolation of a section subjected to a sustained fault to take place without utilizing earth fault current for the operation of protective relays, or pilot wires between sectionalizing stations remote from one another. The scheme provides for the installation of Petersen coils together with special automatic selectors and associated equipment, and has been employed with considerable success since 1936 for protection of the Ganges Canal hydroelectric grid in the United Provinces, India.

The paper shows that by introducing Petersen coils and automatic selector equipment to the system, almost complete immunity from outages due to temporary line-to-earth faults had been achieved, and that in the case of a sustained line-to-earth fault the affected section can be selected and isolated automatically within a period of 30 sec. from the instant of fault, without any 'kick' being experienced by the power stations. No pilot wires are required between selector stations. The existing overload relays continue to protect the system against line-to-line faults, and if desired the original form of earth-leakage protection may be restored to the system by the manipulation of earthing switches.
To certain criticisms of the scheme that $(a)$ there is the possibility of line surges occurring due to switching on a system entirely protected by Petersen coils, and $(b)$ the interruption in supply to substations connected to healthy lines between switching points must of necessity sometimes be experienced, it can be replied that no surge effects have boen observed and the transformers, switchgear and line insulators have not been affected thereby, while since the majority of faults recorded clear before any sectionalizing takes place and as sustained earth faults are infrequent, momentary interruptions to load points are few. The probability of the selectors having to complete full sequence of operation in the event of a sustained earth fault is small, as there are eleven sections on which the fault may have occurred and it is only in the event of the fault being on the last section in the series, or in a substation structure, that the full sequence of operation takes place.

\section{THE TERMITES OF AUSTRALIA}

\author{
By DR. A. D. IMMS, F.R.S.
}

$\mathrm{U}$

NDER the above tit]e there has recently appeared a timely and much needed monograph*. The author, Mr. G. F. Hill, has been an active worker on termites for many years and has an unrivalled acquaintance with these insects in so far as Australia is concerned. There are many difficulties to be contended with in the study and investigation of termites, and it is for this reason that monographs are badly needed from nearly all parts of the world that are inhabited by these creatures. Excluding the United States, which has a relatively meagre termite fauna, Australia is to be commended in giving a leading hand by furthering publication of an account of her native species. But the availability of a competent authority is about two thirds the battleother lands are not so far equally favoured. India, perhaps more than any other part of the British Commonwealth of Nations, needs a proper monograph on her rich and vast termite fauna, that is productive of almost incredible damage to human effort. A sound monograph on this order is worth many of those on the more obscure orders, and it is to be hoped that a competent worker will be forthcoming one day, not too far distant, who will cope with the task.

But, as previously said, the difficulties are manifold when it comes to identifying these insects. The soldier caste affords the best and most reliable character-the winged imagines are seasonal and not so often met with in consequence, while the workers (that have earned for termites their notoriety as destroyers of products serving man's convenience) show ill-defined features that make their specific determination a thing of great uncertainty. Apart from the inciderre, then, of three different castes of individuals in each species, it needs to be taken into account that two or more different species may inhabit the same mound or piece of wood. It often happens that two or more species of very distinct habits are almost indistinguishable in form and structure, and that individuals of the same species may differ very much in different regions so as to be * Termites (Isoptera) from the Australian Region. By Gerald F. Hill. Commonwealth of Australia Council for Scientific and Industrial
Research. 479 pp., 353 text figs. and 24 plates. (Melbourne, 1942.) 
mistaken as belonging to more than a single species. Difficulties of this kind have naturally given rise to much confusion regarding the specific identity of so many of the Australian termites, as elsewhere.

Much spade work has been undertaken by Mr. Hill in getting discrepancies of this type properly cleared up. During the progress of this work about nine thousand termite colonies have been examined. Altogether 217 species have been recorded from the region under review, which includes also New Guinea and islands south of the equator between $140^{\circ} \mathrm{E}$. longitude and $170^{\circ} \mathrm{W}$. longitude.

Among this rich fauna is included the most primitive of all termites-Mastotermes darwiniensis, which happens, also, to be the most destructive among the Australian species. A thorough study of this 'key' form should throw much light on the many outstanding problems of termite economy and would form an admirable subject for a young and promising Australian zoologist to embark upon. The present monograph loses nothing by the letterpress being reproduced photolithographically owing to need for economy, and the line drawings form a valuable adjunet. In a short notice of this kind little more can be written other than to direct attention to the importance and excellence of the work in question, which will probably long remain a standard monograph.

\section{FORTHCOMING EVENTS}

\section{Saturday, July 3}

NUTRTTION SOCIETY (JOINT MEETTNG WITH THE FOOD GROUP OP THE SOCIETY OF CHEMICAL INDUSTRY) (at the London School of Hygiene and Tropical Medicine, Keppel Street, London, W.C.1), at 11 a.M.Discussion on "Milk" (Chairman: Prof. H. D. Kay).

LONDON MATHEMATICAI SOCIETY (JOINT MEETING WITH THE LONDON BRANCH OF THE INSTITUTI OF PHYSICS) (at the Royal Society, Burlington House, Piccadilly, London, W.1), at 2 p.m. - Dr. A. C. Aitken, F.R.S.: "Matrices in Practical Mathematics"; Dr. L. J. Cornrie : "Computational Methods and Mathematical Tables"; Mr. H. L. head: "Applications of Elementary Mathematical" Proeesses, with special reference to Circuit Theory".

\section{Saturday, July 3-Sunday, July 4}

Town aNd COUNTRY PLanning Association (at the Waldorf Hotel, Aldwych, Loudon, W.C.2), at 10.30 a.m.-Conference on "Town Planning, Housing and Full Employment".

Tuesday, July 6

Royai Society of Medrcine (at 1 Wimpole Street, London, W.1), at 5 p.m.-Annual Meeting.

Friday, July 9

Royal Astronomical Societr (at Burlington House, Piccadilly, London, W.1), at 4.30 p.m.-Dr. R. O. Redman: "Spectrographic Observations of the Total Eclipse of 1940 October $1 ; 3$; The "Nectrum of the Extreme Limb of the Sun"; Dr. R. v. d. R. Woolley: visual Magnitudes of Southern Stars".

INSTITUTE OF PHYSTOS (JOINT MEETING WITH THE INSTITUTION OF ELECTRONICS) (in the Reynolds Hall, College of Technology, Sackville Street, Manchester), at 7 p.m.-Dr. A. Sommer: "Photo-electric Cells".

Saturday, July 10

INSTITUTE of PHYSICS (INDUSTRIAX RADIOLOGY GROUP) (at the Institution of Electrical Engineers, Savoy Place, Victoria EmbankRadiology.

\section{APPOINTMENTS VACANT}

Applroations are invited for the following appointments on or before the dates mentioned:

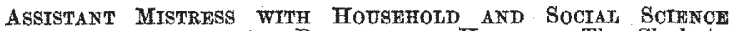
QUALIFTCATIONS, INCLUDING BroLOGY AND HYGIBNE-The Clerk to

Lecturer in Buhining Construction, Geombiry and Schence,

LECTURER IN BUMDING CONSTRUCTION, GEOMEIRY AND Sorence, Newport Technical College-The Director of Education, Education Newport Technical College-The Director of
Offices, Charles Street, Newport, Mon. (July 7).
Assistant Masters for (a) Mathematics, $(b)$ Science, including

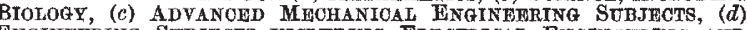
WORGELING SUBJECTS INCLUDING ELECTRTCAT ENGINERRING AND Queensway, Enfleld, Middlesex (July 9).

ASSISTANT MASTER IN THE JUNIOR TECHNICAT SCHOOT, WKLI QUALIFIED TO TRACH MATHEMATICS AND SOTENCE-C'The Principal, Royal Technical College, Peel Park, Salford 5 (July 9).

TEAOHER (TEMPORARY) OF SCIENCE AND MATHEMATICS, and a TEACHER (TEMPORART) OF WORKSHOP PRACTICAL (GNGINEERING) AND TEChNICAL DRAWINe-The Principal, Stockport College for Further Education, Stockport (July 10).

JUNIOR LECTURER AND DFMONSTRATOR IN THE DEPARTMENT OF MECHANICAL FAgINERRING-The Registrar, The University, Liverpool (July 14).

DEMONSTRATOR (MAN OR WOMAN) IN THE PHYSIOLOQY DEPARTMENT The Warden and Secretary, London (Royal Free Hospital) Schoo of Medicine for Women, 8 Hunter Street, London, W.C.1 (July 16).

COMBINED POST OF FULL-TTME (ACTING) RADIOTHERAPIST TO THE Liverpoot Cancer Controt, Organization and (ACTING) MEdical DIRECTOR OF THE RADIOTHERAPEUTIO DEPARTMENT OF THE LIVERPOOL
RADIUM INSTITUTE-The Hon. Secretary, Liverpool Cancer Control Organization, 66 Rodney street, Liverpool 1 (July 24).

Heads of the Departments of Physiology, Medicine, and SURGERY - The Bursar, Royal Veterinary College and Hospital, at The University, Reading (October 1 ).

PSYchIATRId SOCIAL WORKER-The Medical Superintendent, Springfield Mental Hospital, Tooting, London, S.W.17.

TEACHERS (MEN OR WOMEN) FOR THE FOLLOWING SUBJECTS FOR THE DaY Sohool: JONIOR Mathematics ; Mathematios ; Grography ; GENERAL SCrENCE-The Clerk to the Governors, South-West Eissex London, E.17.

TEACHER OF ENGINeEring SURJects-The Principal, Technical Institute and Day Technical School for Boys, Gravesend.

Schende Master to TEACH MatNLY BIOLOGY in connexion with a Pre-Agricultural Course for Boys in the Maidstone Technical Institute The District Secretary, Mr. A. W. Peacock, 13 Tonbridge Road, Maidstone.

Central Production Engineer-The Ministry of Labour and National Service, Central (Technical and Scientific) Register (Reference No. C.1609X), Alexandra House, Kingsway, London, W.C.2.

ENGINEER (temporary staff) for the Nigerian Government Public Works Department-The Ministry of Labour and National Service, Central (Technical and Scientific) Register (Reference E.684), Alexandra House, Kingsway, London, W.C.2.

\section{REPORTS and other PUBLICATIONS (not included in the monthly Books Supplement)} Great Britain and Ireland

Philosophical Transactions of the Royal Society of London. Series A : Mathematical and Physical Sciences. Vol. 239, No. 806: The Negative Ions of Atomic and Molecular Oxygen. By D. R. Bates and H. S. W. Massey. Pp. 269-304. (Tondon: Cambridge University
Press.) $58.6 d$. Association of Special Libraries and Information Bureaux. ASLIB War-time Guides to British Sources of Specialised Information, No. 5: Fnginecring, other than Electrical. Pp. ii + 38. (London : Association of Special Libraries and Information Bureaux.) 58.; to nonmembers, 68 .

[315

University of London. Report of the Acting Principal on the Work of the University during the Year 1942-43. Pp. 8. (London: Univery of London.

Institute of Welding: Welding Research Council. Memorandum on Deep Penetration Fillet Welding. Prepared by the R.49 SubCommittee on Are Welding Procedure for Shipbuilding. (T.11.) Pp. 4.
(London: Institute of Welding.)
[16 Medical Research Council. War Memorandum No. 2: Notes on Gas Gangrene ; Prevention, Diagnosis, Treatment. With an Account of the Technique of Wound-Excision and a Scheme for the Bacteriological Investigation of War Wounds. By the War Wounds Committee of the Medical Research Council and the Committee of London Sector Pathologists. Revised second edition. Pp. 28. (London: H.M.
Stationery Office.) 6d. net.

\section{Other Countries}

Proceedings of the United States National Museum. Vol. 93, No. 3162: A New Pest of Albizzia in the District of Columbia (Lepidoptera: Glyphipterygidae). By J. F. Gates Clarke. Pp. 205-208+ Carnegie Institution of Washington. Year Book No. 41, July 1, 1941-June 30, 1942. With Administrative Book No. 41, July 1, $1941-J$ une 30,1942 ; with Administrative Reports through Decem-
ber 18, 1942. Pp. Xxxii $+9+309$. (Washington, D.C.: Smithsonian ber 18, 1942. Pp. xxxii $+9+309$. (Washington, D.C. : Smithsonian
Institution.)

Annals of the New York Academy of Sciences. Vol. 43, Art. 6 : Protein Hormones of the Pituitary Body. By H. B. van Dyke, Bacon F. Chow, Vincent du Vigneaud, H. L. Fevold, George W. Irving, Jr., C. N. H. Long, Theodore Shedlovsky and Abraham White. Pp. 253-
426. (New York: New York Academy of Sciences.) Indian Forest Records (New Series). Entomology, Vol. 7, No. 4: Immature Stages of Indian Lepidoptera (4) Zygaenidae. By'J. C. M. Gardner. Pp. ii $+155-162+1$ plate. (Delhi : Manager of Publications.) 7 annas; $8 d$.

Indian Forest Bulletin No. 117: The Testing of Packing-Cases and some Suggested Improvements in the Design of such Boxes. By V. D. Limaye. Pp. 11. (Dehra Dun: Forest Research Institute.) [86 